\title{
Kontribusi Pupuk Hayati dan Pupuk Anorganik untuk Meningkatkan Pertumbuhan dan Hasil Tanaman Padi Gogo pada Ultisols Jatinangor
}

\author{
Betty Natalie Fitriatin'1), Muthia Erwina Nabila'2), Tien Turmuktini1'), Emma Trinurani \\ Sofyan'1), dan Anni Yuniarti1) \\ 1)Departemen Ilmu Tanah dan Sumberdaya Lahan, Fakultas Pertanian Universitas Padjadjaran \\ Jl. Raya Bandung Sumedang Km 21 Jatinangor \\ 2)Program Studi Agroteknologi, Fakultas Pertanian Universitas Winaya Mukti \\ Jl. Raya Bandung-Sumedang KM 29 Tanjungsari.
}

Korespondensi: betty.natalie@unpad.ac.id

\begin{abstract}
Ultisols have low soil fertility problems. Beneficial microbes such as biofertilizers could improve soil fertility and the productivity of Ultisols sustainability. The purpose of this research was to study the contribution of biofertilizers and NPK fertilizers to increase growth and yield of upland rice on Utisols. This experiment used a Randomized Block Design (RBD) in factorial pattern, consisting of two factors with three replications. The first factor consisted of biofertilizer, which were; without biofertilizer, biofertilizer consortia A (Pseudomonas mallei, P. cepaceae, Aspergillus niger and Penicillium sp., Azotobacter chroococum, Azospirillum sp.) biofertilizer consortia $B$ (Azotobacter choroococum, A. viilandii, Azospirillum, Pseudomonas cepaceae, Penicillium and Acitenobacter) and biofertizer consortia $A+B$. The second factor were NPK fertilizers with four levels ( $100 \%, 75 \%, 50 \%$ and $25 \%$ dosage of recomendation). The results showed that the application of biofertilizer consortia increased growth of upland rice on Ultisols Jatinangor.
\end{abstract}

Keywords : biofertilizers consortia, Ultisols, upland rice

\section{PENDAHULUAN}

Peningkatan jumlah penduduk di Indonesia termasuk yang sangat tinggi di dunia. Akibat jumlah penduduk yang tinggi ini mengakibatkan peningkatan tajam terhadap kebutuhan pagan dan tempat tinggal. Banyaknya kebutuhan pangan memicu alih fugsi sawah menjadi sektor perumahan. Sehingga padi sebagai tananam untuk kebutuhan pokok banyak ditanam pada lahan kering.

Lahan kering di Indonesia didominasi oleh ordo tanah Ultisols dan Inceptisols. Ultisol merupakan salah satu tanah kering di Indonesia yang mempunyai sebaran yang luas, mencapai 45.794 .000 ha atau sekitar $25 \%$ dari total luas daratan Indonesia (Subagyo dkk., 2004). Reaksi Ultisols pada umumnya masam hingga sangat masam. Kandungan Al yang tinggi merupakan permasalahan yang terdapat pada Ultisol yaitu menyebabkan fiksasi unsur fosfat. Kendala lain yaitu kandungan unsur hara makro yang rendah (Hardjowigeno, 2010). Sebaran Ultisol yang luas ini merupakan potensi dalam pengembangan pertanian lahan kering yang optimal dan berkelanjutan.

Salah satu upaya meningkatkan produktivitas Ultisols yang berkelanjutan dapat dilakukan dengan aplikasi pupuk hayati (Fitriatin et. al., 2014) Pupuk hayati merupakan suatu bahan amademen yang mengandung mikroba bermanfaat untuk meningkatkan kesuburan tanah dan pertumbuhan tanaman yang optimal sehingga diperoleh produksi tanaman yang maksimum (Rao, 1994). Mikroba yang umum digunakan sebagai bahan aktif pupuk hayati yaitu bakteri penambat nitrogen, mikroorganisme pelarut fosfat, mikoriza, dan bakteri penghasil fitohormon (Vessey, 2003). Itelima et. al. (2018) menyatakan pupuk hayati berperan penting untuk meningkatkan produktivias lahan secara berkelanjutan serta mempengaruhi secara positif terhadap pertumbuhan dan hasil tanaman.

Aplikasi pupuk hayati telah diketahui mampu meningkatkan efisiensi pupuk anor- 
ganik (Fitriatin et. al. 2018). Penelitian ini bertujuan untuk mengetahui peranan pupuk hayati dan NPK terhadap pertumbuhan dan hasil tanaman padi gogo pada Ultisols Jatinangor.

\section{METODOLOGI}

Percobaan dilaksanakan di rumah kaca Fakultas Pertanian Universitas Padjadjaran di Jatinangor. Tanah yang digunakan sebagai media tanam yaitu ordo Ultisols asal Jatinangor ( $\mathrm{pH} \mathrm{H}_{2} \mathrm{O}$ 4,8 (masam); $\mathrm{N}$ total sebesar $0,069 \%$ (sangat rendah), P-tersedia $\left(\mathrm{P}_{2} \mathrm{O}_{5}\right)$ 9,87 mg kg-1 (sangat rendah), $\mathrm{P}-$ potensial $\left(\mathrm{P}_{2} \mathrm{O}_{5} \mathrm{HCl} 25 \%\right) 18,29 \mathrm{mg} 100 \mathrm{~g}^{-1}$ (kriteria rendah). Benih padi gogo mengunakan varietas Situ Bagendit. Pupuk hayati yang digunakan merupakan konsorsium antara mikroorganisme pelarut $\mathrm{P}$ dan pemfiksasi $\mathrm{N}$ koleksi Laboratorium Biologi Tanah Fakultas Pertanian UNPAD.

Rancangan percobaan yang digunakan adalah RAK faktorial yang terdiri dari dua faktor dengan tiga ulangan. Faktor pertama adalah pupuk hayati yang terdiri dari empat taraf:

- Tanpa pupuk hayati

- Konsorsium A (Pseudomonas mallei, P.cepaceae, A.niger, Penicillium sp, Azotobacer chroococum, Azospirilum sp.)

- Konsorsium B (P. cepaceae, Azotobacer chroococum, A. vilandii, Azospirilum, Penicillium, Acitenobacater)

- Campuran konsorsium A + B.

Faktor kedua adalah dosis pupuk N, P dan $\mathrm{K}$ yang terdiri dari empat taraf, yaitu: $100 \%$, $75 \%, 50 \%$, dan 25\% dosis rekomendasi. Dosis pupuk hayati yaitu $50 \mathrm{~kg} \mathrm{ha}^{-1}$ sedangkan dosis rekomendasi pupuk NPK yaitu Urea $250 \mathrm{~kg}$ ha${ }^{1}$, SP-36 $100 \mathrm{~kg} \mathrm{ha}^{-1}, \mathrm{KCl} 100 \mathrm{~kg} \mathrm{ha}^{-1}$.

Variabel respon yang diamati adalah pertumbuhan tanaman dengan parameter tinggi tanaman dan jumlah anakan. Pengamatan dilakukan secara periodik sampai fase vegetatif akhir. Faktor lain yang diamati adalah bobot gabah kering.
Pembuatan pupuk hayati dilakukan dengan cara melarutkan biakan murni isolat $\mathrm{BPF}, \mathrm{JPF}$, dan isolat-isolat bakteri penambat nitrogen dengan $\mathrm{NaCl}$ fisiologis $0,85 \%$ hingga mencapai $10 \mathrm{ml}$. Isolat dipindahkan ke tabung Erlenmeyer yang berisi media perbanyakan. Perbanyakan isolat bakteri pelarut fosfat dan bakteri pemfiksasi nitrogen menggunakan nutrient broth (NB) sedangkan jamur pelarut fosfat menggunakan potato dextrose broth (PDB). Masing-masing biakan murni dari setiap isolat dimasukan ke dalam media perbanyakan sebanyak $10 \%$ dari volume media selanjutnya dikocok dengan shaker 112 rpm selama 3 hari dan Dilakukan perhitungan populasi terlebih dahulu terhadap BPF, JPF serta bakteri pemfikasi $\mathrm{N}$ dengan metode Total Plate Count sebelum dimasukkan ke dalam bahan pembawa yaitu campuran gambut dan kompos perbandingan 1:1 sebanyak $10 \%$ volume berat.

Pupuk hayati yang digunakan merupakan pupuk hayati dalam bentuk padat dengan kepadatan bakteri $10^{8}$ berdasarkan hasil analisis awal populasi mikroba konsorsium pupuk hayati. Dosis yang diberikan yaitu 50 $\mathrm{kg} /$ ha atau $0.375 \mathrm{~g} /$ pot. Pemberian pupuk hayati pada tanah dilakukan dengan cara mencampurkan pupuk hayati dengan pupuk organik (kompos jerami) sebanyak 10.000 $\mathrm{kg} / \mathrm{ha}$ atau $75 \mathrm{~g} /$ pot lalu dibenamkan di dalam pot.

\section{HASIL DAN PEMBAHASAN}

\subsection{Pertumbuhan Padi Gogo}

Hasil percobaan menunjukkan terjadi interaksi antara pupuk hayati dan pupuk N, P, $\mathrm{K}$ terhadap pertumbuhan tanaman berupa tinggi tanaman pada umur 4 dan 6 minggu setelah tanam (MST). Aplikasi pupuk hayati konsorsium A (Pseudomonas mallei, P.cepaceae, A.niger, Penicillium sp, Azotobacer chroococum, Azospirilum sp.) mampu meningkatkan tinggi tanaman secara nyata pada dosis pemberian pupuk NPK 25-50 \% rekomendasi. Hal ini menunjukkan bahwa pemberian pupuk hayati mampu mening- 
katkan pertumbuhann tanaman serta dapat mengurangi kebutuhan pupuk anorganik. Hal ini membutikan bahwa pupuk hayati berupa konsorsium mikroba pelarut fosfat dan bakteri pemfiksasi $\mathrm{N}$ dapat meningkatkan pertumbuhan tanaman. Hal ini diperkuat oleh pernyataan Itelima et. al. (2018), bahwa pupuk hayati mampu meningkatkan pertumbuhan tanaman dan produktivitas lahan secara berkelanjutan. Hasil penelitian Biswakarma et. al. (2018) menunjukkan bahwa aplikasi pupuk hayati bakteri pelarut fosfat dan pupuk NPK mampu meningkatkan tinggi tanaman padi.

Tabel 1 Pengaruh pupuk hayati dan pupuk N, P, K terhadap tinggi tanaman pada 4 MST

\begin{tabular}{ccccc}
\hline \multirow{2}{*}{ Pupuk Hayati (H) } & \multicolumn{4}{c}{ Pupuk NPK (P) } \\
\cline { 2 - 5 } & $100 \%$ & $75 \%$ & $50 \%$ & $25 \%$ \\
\hline \multirow{2}{*}{ Tanpa } & $29,84 \mathrm{~B}$ & $28,60 \mathrm{~B}$ & $24,07 \mathrm{AB}$ & $22,54 \mathrm{~A}$ \\
& $\mathrm{~b}$ & $\mathrm{a}$ & $\mathrm{a}$ & $\mathrm{a}$ \\
Konsorsium A & $23,87 \mathrm{~A}$ & $26,68 \mathrm{AB}$ & $28,07 \mathrm{~B}$ & $25,73 \mathrm{AB}$ \\
& $\mathrm{a}$ & $\mathrm{a}$ & $\mathrm{ab}$ & $\mathrm{a}$ \\
Konsorsium B & $29,14 \mathrm{~A}$ & $28,44 \mathrm{~A}$ & $29,92 \mathrm{~A}$ & $27,44 \mathrm{~A}$ \\
& $\mathrm{~b}$ & $\mathrm{a}$ & $\mathrm{b}$ & $\mathrm{a}$ \\
Konsorsium A dan B & $20,83 \mathrm{~A}$ & $26,79 \mathrm{~B}$ & $29,22 \mathrm{~B}$ & $25,79 \mathrm{~B}$ \\
& $\mathrm{a}$ & $\mathrm{a}$ & $\mathrm{a}$ & $\mathrm{a}$ \\
\hline
\end{tabular}

Keterangan: Angka rata-rata yang diikuti huruf kapital (arah vertikal) yang sama dan huruf kecil (arah horizontal) yang sama tidak berbeda nyata menurut Uji Jarak Berganda Duncan pada taraf nyata $5 \%$.

Pengamatan tinggi tanaman pada 6 MST (Tabel 2) menunjukkan bahwa perlakuan yang berpotensi memberikan peningkatan tinggi tanaman tanaman yaitu perlakuan pupuk hayati konsorsium B (P. cepaceae, Azotobacer chroococum, A. vilandii, Azospirilum, Penicillium, Acitenobacater) dengan dosis pupuk N, P, K 50\% dan $100 \%$ meskipun tidak berbeda nyata dengan perlakuan tanpa pupuk hayati dan dosis $\mathrm{N}, \mathrm{P}$, $\mathrm{K}$ 100\% (kontrol). Hal ini menunjukkan bahwa dengan aplikasi pupuk hayati konsorsium gabungan diikuti dengan penurunan dosis $\mathrm{N}, \mathrm{P}, \mathrm{K}$ dapat memberikan pengaruh yang sama dengan pemberian pupuk N, P, K 100\%.

Tabel 2 Pengaruh pupuk hayati dan pupuk N, P, K terhadap tinggi tanaman pada 6 MST

\begin{tabular}{ccccc}
\hline \multirow{2}{*}{ Pupuk Hayati (H) } & \multicolumn{4}{c}{ Pupuk NPK (P) } \\
\cline { 2 - 5 } & $100 \%$ & $75 \%$ & $50 \%$ & $25 \%$ \\
\hline \multirow{2}{*}{ Tanpa } & $52,33 \mathrm{~A}$ & $45,58 \mathrm{~A}$ & $49,05 \mathrm{~A}$ & $46,93 \mathrm{~A}$ \\
& $\mathrm{~b}$ & $\mathrm{a}$ & $\mathrm{a}$ & $\mathrm{a}$ \\
Konsorsium A & $52,18 \mathrm{~A}$ & $46,71 \mathrm{~A}$ & $50,5 \mathrm{~A}$ & $49,53 \mathrm{~A}$ \\
& $\mathrm{~b}$ & $\mathrm{a}$ & $\mathrm{a}$ & $\mathrm{a}$ \\
Konsorsium B & $48,33 \mathrm{~A}$ & $52,25 \mathrm{AB}$ & $55,89 \mathrm{~B}$ & $47,33 \mathrm{~A}$ \\
& $\mathrm{ab}$ & $\mathrm{a}$ & $\mathrm{b}$ & $\mathrm{a}$ \\
Konsorsium A dan B & $39,45 \mathrm{~A}$ & $46.05 \mathrm{~A}$ & $46,7 \mathrm{~A}$ & $41,25 \mathrm{~A}$ \\
& $\mathrm{a}$ & a & a & a \\
\hline Keterangan: Angka rata-rata yang diikuti huruf kapital (arah vertikal) yang sama dan huruf kecil (arah horizontal) \\
yang sama tidak berbeda nyata menurut Uji Jarak Berganda Duncan pada taraf nyata 5\%.
\end{tabular}

Tabel 2 menunjukkan bahwa aplikasi perlakuan tanpa pupuk hayati, pupuk hayati konsorsium A berpotensi memberikan peningkatan tinggi tanaman padi gogo meskipun tidak berbeda nyata pada perlakuan konsorsium B dengan dosis N, P, K 100\%. Perlakuan pupuk hayati konsorsium B dan pupuk N, P, K dosis $50 \%$ berpotensi 
meningkatkan tinggi tanaman padi gogo meskipun tidak berbeda nyata dengan pupuk hayati konsorsium B dan N, P, K 100\% saat tanaman mencapai umur 6 MST. Hal ini membuktikan bahwa penurunan dosis $\mathrm{N}, \mathrm{P}, \mathrm{K}$ dapat dikurangi dengan pemberian pupuk hayati konsorsium.

Pengamatan terhadap jumlah anakan menunjukkan saat tanaman padi gogo berumur 4 MST perlakuan pupuk N, P, K dosis $100 \%$ dan dikombinasikan dengan pupuk hayati konsorsium A atau B memberikan pengaruh secara nyata dengan jumlah anakan lebih banyak dibandingkan engan tanpa dan pupuk hayati konsorsium A dan B (Tabel 3). Hal ini dikarenakan pertumbuhan tanaman terjadi karena adanya proses-proses pembela- han sel dan pemanjangan sel dimana prosesproses tersebut memerlukan karbohidrat dalam jumlah besar. Gardner et. al. (1991) menyatakan bahwa pertumbuhan dan hasil suatu tanaman dipengaruhi oleh keadaan lingkungan tumbuhnya.

Salah satu faktor lingkungan tumbuh yang penting bagi pertumbuhan tanaman adalah ketersediaan unsur hara. Pada jenis pupuk hayati konsorsium B penurunan dosis $\mathrm{N}, \mathrm{P}, \mathrm{K}$ hingga $50 \%$ dapat memberikan pengaruh nyata terhadap jumlah anakan tanaman padi gogo. Dosis N, P, K 25 \% yang dikombinasikan dengan pupuk hayati konsorsium A dan B memberikan hasil yang berbeda nyata terhadap pertambahan jumlah anakan.

Tabel 3 Pengaruh pupuk hayati dan dosis pupuk N, P, terhadap jumlah anakan tanaman padi 4 MST.

\begin{tabular}{lcccc}
\hline \multirow{2}{*}{ Pupuk Hayati $(\mathrm{H})$} & \multicolumn{4}{c}{ Pupuk N, P, K (P) } \\
\cline { 2 - 5 } Tanpa & $100 \%$ & $75 \%$ & $50 \%$ & $25 \%$ \\
\hline \multirow{3}{*}{ Konsorsium A } & $3,33 \mathrm{~A}$ & $3,00 \mathrm{~A}$ & $3,33 \mathrm{~A}$ & $3,17 \mathrm{~A}$ \\
& $\mathrm{a}$ & $\mathrm{a}$ & $\mathrm{a}$ & $\mathrm{a}$ \\
Konsorsium B & $4,50 \mathrm{~B}$ & $3,00 \mathrm{~A}$ & $3,33 \mathrm{~A}$ & $3,67 \mathrm{AB}$ \\
& $\mathrm{b}$ & $\mathrm{a}$ & $\mathrm{a}$ & $\mathrm{a}$ \\
Konsorsium A dan B & $3,33 \mathrm{~A}$ & $4,33 \mathrm{~B}$ & $4,37 \mathrm{~B}$ & $3,67 \mathrm{AB}$ \\
& $\mathrm{b}$ & $\mathrm{a}$ & $\mathrm{a}$ & $\mathrm{a}$ \\
& $3,17 \mathrm{~A}$ & $3,67 \mathrm{AB}$ & $3,33 \mathrm{AB}$ & $4,33 \mathrm{~B}$ \\
& $\mathrm{a}$ & $\mathrm{a}$ & $\mathrm{a}$ & $\mathrm{a}$ \\
\hline
\end{tabular}

Keterangan: Angka rata-rata yang diikuti huruf kapital (arah vertikal) yang sama dan huruf kecil (arah horizontal) yang sama tidak berbeda nyata menurut Uji Jarak Berganda Duncan pada taraf nyata 5\%.

Tabel 4 menunjukkan bahwa pemberian pupuk N, P, K dosis 50\% yang dikombinasikan dengan pupuk hayati konsorsium B menunjukkan peningkatan jumlah anakan hingga $2 \%$ dibandingkan dengan dosis $\mathrm{N}, \mathrm{P}, \mathrm{K}$ $100 \%$ dan tanpa pupuk hayati ketika dilakukan pengamatan 6 MST. Hal ini disebabkan mikroba yang terdapat pada pupuk hayati dapat membantu dalam pertumbuhan tanaman melalui produksi substansi zat pengatur tumbuh seperti giberelin, sitokinin asam indol asetat (IAA), dan dapat memacu pertumbuhan akar (Rahmi, 2014), sehingga dengan diproduksi IAA oleh bakteri penambat $\mathrm{N}$ maka pemupukan dapat menjadi lebih efisien (Akbari dkk, 2007).
Aplikasi pupuk N, P, K dapat menyediakan nutrisi secara cepat bagi tanaman serta mikroba yang terkandung di dalam pupuk hayati mampu membantu penyediaan hara yang dibutuhkan tanaman padi gogo sehingga pertambahan jumlah anakan tanaman dapat terjadi. Bakteri yang diinokulasikan pada pupuk hayati konsorsium B didominasi oleh bakteri pemfiksasi unsur $\mathrm{N}$ sehingga dapat memberikan jumlah anakan yang paling baik dibandingkan dengan perlakuan lainnya. Hal ini sesuai dengan pendapat Rauf dkk (2000) yang menyatakan unsur $\mathrm{N}$ merupakan unsur yang cepat terlihat pengaruhnya terhadap tanaman, meningkatkan jumlah anakan dan meningkatkan jumlah bulir per rumpun. 
Perlakuan yang diberikan tidak berbeda nyata pada pengamatan 2 MST diduga hal ini karena bakteri yang diinokulasikan belum dapat beradaptasi dengan baik atau masih dalam fase lag (pertumbuhan lambat) sedangkan ketika tanaman mencapai usia 8 - 10 MST diduga bakteri telah memasuki fase stationer sehingga bakteri sudah tidak lagi memberikan pengaruh secara signifikan terhadap pertambahan jumlah anakan.

Tabel 4 Pengaruh pupuk hayati dan dosis pupuk N, P, K terhadap jumlah anakan tanaman padi pada 6 MST

\begin{tabular}{lcccc}
\hline \multirow{2}{*}{ Pupuk Hayati (H) } & \multicolumn{4}{c}{ Pupuk N, P, K (P) } \\
\cline { 2 - 5 } & $\mathbf{1 0 0 \%}$ & $\mathbf{7 5 \%}$ & $\mathbf{5 0 \%}$ & $\mathbf{2 5 \%}$ \\
\hline Tanpa & $4,40 \mathrm{~A}$ & $5,71 \mathrm{~A}$ & $4,57 \mathrm{~A}$ & $4,37 \mathrm{~A}$ \\
Konsorsium A & $\mathrm{a}$ & $\mathrm{a}$ & $\mathrm{a}$ & $\mathrm{a}$ \\
& $5,56 \mathrm{~A}$ & $4,37 \mathrm{~A}$ & $6,17 \mathrm{~A}$ & $4,67 \mathrm{~A}$ \\
Konsorsium B & $\mathrm{a}$ & $\mathrm{a}$ & $\mathrm{a}$ & $\mathrm{a}$ \\
& $4,87 \mathrm{~A}$ & $5,75 \mathrm{AB}$ & $6,80 \mathrm{~B}$ & $4,67 \mathrm{~A}$ \\
Konsorsium A dan B & $\mathrm{a}$ & $\mathrm{a}$ & $\mathrm{b}$ & $\mathrm{a}$ \\
& $6,00 \mathrm{~B}$ & $4,93 \mathrm{~A}$ & $4,70 \mathrm{~A}$ & $4,73 \mathrm{~A}$ \\
\hline
\end{tabular}

Keterangan: Angka rata-rata yang diikuti huruf kapital (arah vertikal) yang sama dan huruf kecil (arah horizontal) yang sama tidak berbeda nyata menurut Uji Jarak Berganda Duncan pada taraf nyata 5\%.

\subsection{Hasil Padi Gogo}

Hasil analisis statistik menunjukkan terdapat interaksi antara pemberian pupuk hayati konsorsium dan pupuk N, P, dan K terhadap bobot gabah kering panen. Berdasarkan hasil uji lanjut Duncan dapat terlihat bahwa kombinasi perlakuan pupuk hayati konsorsium dan pupuk N, P, K dan berbeda nyata lebih baik pada bobot gabah kering panen (Tabel 5). Pada kombinasi pupuk N, $\mathrm{P}, \mathrm{K}$ dosis $75 \%$ dengan pupuk hayati konsorsium A dan gabungan (A dan B) berpotensi meningkatkan hasil bobot gabah kering panen meskipun tidak berbeda nyata secara signifikan dnegan perlakuan pupuk hayati konsorsium A dan dosis pupuk N, P, K $100 \%$ serta pupuk hayati konsorsium B dengan dosis pupuk N, P, K 50\% . Aplikasi pupuk hayati konsorsium $\mathrm{B}$ dikombinasikan dengan pupuk N, P, K dosis $50 \%$ berpotensi dalam penigkatan hasil gabah kering panen walaupun tidak berbeda nyata dengan pupuk hayati konsorsium B pada dosis N, P, K 75\% yang berbeda nyata apabila dibandingkan dengan pupuk hayati konsorsium lainnya pada dosis pupuk $\mathrm{N}, \mathrm{P}, \mathrm{K}$ yang sama.

Tabel 5 Pengaruh pupuk hayati dan pupuk N, P, dan K terhadap bobot gabah kering panen (gr/tanaman).

\begin{tabular}{lcccc}
\hline \multirow{2}{*}{ Pupuk Hayati $(\mathrm{H})$} & \multicolumn{4}{c}{ Pupuk N, P, K (P) } \\
\cline { 2 - 5 } & $100 \%$ & $75 \%$ & $50 \%$ & $25 \%$ \\
\hline \multirow{2}{*}{ Tanpa } & $27,74 \mathrm{~A}$ & $25,37 \mathrm{~A}$ & $28,68 \mathrm{~A}$ & $29,01 \mathrm{~A}$ \\
\multirow{2}{*}{ Konsorsium A } & $\mathrm{a}$ & $\mathrm{a}$ & $\mathrm{a}$ & $\mathrm{a}$ \\
& $28,42 \mathrm{AB}$ & $32,80 \mathrm{~B}$ & $25,2 \mathrm{~A}$ & $25,50 \mathrm{~A}$ \\
Konsorsium B & $\mathrm{a}$ & $\mathrm{b}$ & $\mathrm{a}$ & $\mathrm{a}$ \\
& $26,72 \mathrm{~A}$ & $33,05 \mathrm{~B}$ & $34,3 \mathrm{~B}$ & $27,06 \mathrm{~A}$ \\
\multirow{2}{*}{ Konsorsium A dan B } & $\mathrm{a}$ & $\mathrm{ab}$ & $\mathrm{b}$ & $\mathrm{a}$ \\
& $25,8 \mathrm{~A}$ & $32,16 \mathrm{~B}$ & $29,24 \mathrm{~A}$ & $27,08 \mathrm{~A}$ \\
& $\mathrm{a}$ & $\mathrm{b}$ & $\mathrm{a}$ & $\mathrm{a}$ \\
\hline
\end{tabular}

Keterangan: Angka rata-rata yang diikuti huruf kapital (arah vertikal) yang sama dan huruf kecil (arah horizontal) yang sama tidak berbeda nyata menurut Uji Jarak Berganda Duncan pada taraf nyata 5\%.

Hasil percobaan menunjukkan bahwa dengan penurunan dosis pupuk $\mathrm{N}, \mathrm{P}, \mathrm{K}$ dan diberikan pupuk hayati mampu memberikan hasil gabah kering panen yang lebih baik 
apabila dibandingkan dengan hanya pemberian pupuk N, P, K 100\%. Itelima et. al. (2018), menyatakan bahwa pupuk hayati dapat berguna dalam mereduksi pupuk anorganik namun tidak mengurangi hasil panen tanaman, dapat menyuburkan tanah, memperbaiki struktur tanah, serta membantu penanggulangan penyakit yang berasal dari tanah.

Aplikasi pupuk hayati konsorsium B didominasi oleh bakteri pemfiksasi $\mathrm{N}$ apabila dibandingkan dengan pupuk hayati konsorsium A namun tetap pada komposisi yang beriimbang, sehingga mampu memberikan pengaruh yang cenderung lebih baik terhadap bobot gabah kering panen dibandingkan dengan pupuk hayati konsorsium A maupun konsorsium gabungan pada dosis N, P, K 50\%. Hasil penelitian Saba et. al. (2013) menunjukkan bahwa aplikasi pupuk hayati mampu mengurangi kebutuhan pupuk sintetik pada tanaman padi.

Pada pupuk hayati konsorsium gabungan (A dan B) tidak memberikan pengaruh secara nyata pada dosis N, P, K 50\% diduga hal ini dikarenakan tingginya persaingan unsur hara mikroba dalam memperoleh makanan yang menyebabkan kebutuhan nutrisi mikroba kurang terpenuhi sehingga mikroba bekerja kurang optimal yang menyebabkan bobot gabah kering pada pupuk hayati konsorsium gabungan menjadi kurang optimal (Simanungkalit, 2006).

\section{KESIMPULAN}

Hasil percobaan dari pengaruh aplikasi pupuk hayati dan pupuk anorganik berupa N,P dan $\mathrm{K}$ diperoleh bahwa interaksi antara pupuk hayati dan pupuk $\mathrm{N}, \mathrm{P}, \mathrm{K}$ meningkatkan secara nyata pertumbuhan tanaman berupa tinggi tanaman dan jumlah anakan pada umur 4 MST dan 6 MST dan hasil panen berupa bbobot gabah kering panen. Aplikasi pupuk hayati konsorsium B (P. cepaceae, Azotobacer chroococum, A. vilandii, Azospirilum, Penicillium, Acitenobacater) dengan pemberian pupuk N.P,K dosis $50 \%$ rekomendasi menigkatkan secara nyata bobot gabah kering panen dengan hasil sebesar 34,3 $\mathrm{g} /$ tanaman.

\section{Ucapan Terimaksih}

Terima kasih dan penghargaan setingitingginya disampaikan kepada Kemenristekdikti yang mendanai penelitian Strategis Nasional Institusi tahun 2018 (16/UN6.E/LT/2018). Ucapan terima kasih disampaikan kepada Rektor UNPAD, Direktur Riset dan Pengadian Kepada Masyarakat UNPAD dan Dekan Fakultas Pertanian atas dukungan dan kerjasamanya. Ucapan terima kasih juga kami sampaikan kepada saudara Muthia Erwina Nabila dan Yuni yang telah banyak membantu pelaksanaan penelitian.

\section{DAFTAR PUSTAKA}

Akbari, Gh. Abbas, S.M. Arab, H.A. Alikhani, I. Allahdadi, and M.H. Arzanesh. 2007. Isolation and selection of indigenous Azospirilum spp. and the IAA of superior strains effects on wheat roots. World Journal of Agricultural Sciences 3 (4):523-529.

Biswakarma, B., H. Verma and N.C. Sarkar. 2018. Effect of phosphate solubilizing bacteria on yield of transplanted rice under lateritic belt of West Bengal, India. International Journal of Current Microbiology and Applied Sciences 7(2): 3192-3204.

Fitriatin, B.N. , A. Yuniarti, and T. Turmuktini. 2014. The effect of phosphate solubilizing microbe producing growth regulators on soil phosphate, growth and yield of maize and fertilizer efficiency on Ultisol. Eurasian Journal of Soil Science. 3: $104-107$.

Fitriatin, B.N., P. Tamara, O. Mulyani, E.T. Sofyan, A.Yuniarti and T. Turmuktini. 2018. Influence of biofertilizer and humic acid on NPK content and yield of rice (Oryza sativa L.). International 
Journal of Agriculture, Environment and Bioresearch 3: 20-27.

Gardner, F. P., R. B. Pearce, dan R. L. Mitchell, 1991. Fisiologi Tanaman Budidaya. Terjemahan oleh: Herawati Susilo. University of Indonesia Press. Jakarta.

Hardjowigeno, S. 2010. Ilmu Tanah. Akademika Presindo, Jakarta.

Itelima, J.U., W.J. Bang, M.D. Sila, I.A. Onyimba, and 0.J. Egbere. 2018. A review:

Biofertilizer - A key player in enhancing soil fertility and crop productivity. Microbiol Biotechnol Rep 2(1):22-28.

Rao, N. S. S. 1994. Mikroorganisme Tanah dan Pertumbuhan Tanaman. Edisi 2. Diterjemahkan oleh: Herawati Susilo. Jakarta: UI-Press.

Rauf, A.W., T. Syamsuddin, S. R. Sihombing. 2000. Peranan Pupuk NPK pada Tanaman Padi. Loka Pengkajian Teknologi Pertanian No.01/LPTP/IRJA/99-00: 211-219.

Saba, N., I.U. Awan, M.S. Baloch, I.H. Shah, M.A. Nadim, and J. Qadir. 2013. Improving synthetic fertilizer use efficiency through bio-fertilizer application in rice. Gomal University Journal of Research, 29(2): 32-28.

Simanungkalit, R.D.M. 2006. Prospek pupuk organik dan hayati. Dalam Simanungkalit dkk. (Eds). Pupuk Organik dan Pupuk Hayati. Balai Besar Penelitian dan Pengembangan Sumberdaya Lahan Pertanian. Hlm $265-272$.

Subagyo, H. N. Suharta, dan A.B. Siswanto. 2004. Tanah-tanah pertanian di Indonesia. Dalam Pusat Penelitian Tanah dan Agroklimat. Sumberdaya lahan Indonesia dan Pengelolaannya.. Badan Penelitian dan Pengembangan Pertanian, Departemen Pertanian, Bogor. Hlm. 21-66
Vessey, J.K. 2003. Plant growth promoting rhizobacteria as biofertilizer. Plant Soil 255(2): 571-586. 